A publication of the Muma College of Business | University of South Florida

KEVIN DEARY, TINA HERIG, BRENT HINSON, ERIC MARTINEZ

\title{
CENTRALIZATION: OPENING THE WINDOW OF OPPORTUNITY ${ }^{1}$
}

"We open windows for others" is Legit Global's stated purpose... was centralized engineering the key to unlocking efficiency and helping others to open the window to opportunity?

Edgar Madera, the Global Director of Engineering for Strategic and Capital Projects at Legit Global had been under a great deal of pressure lately; Madera had been tasked by Tad Legit, the Executive Vice President (EVP) at Legit Global to centralize engineering processes. Madera had worked with Legit long enough to know quick decisions that produced significant impacts were the expectation of the EVP. Legit had envisioned centralized engineering as an opportunity to reduce costs since the product demand softened in 2019 and was predicted to stay flat in 2020. In Legit Global, the Engineering and Quality Department had operated processes and standards independently and did not share best practices across the Department. The rest of the functional groups, e.g. Finance and Accounting, were centralized a few years back and were reaping benefits for the company. How much more time was Madera afforded to centralize engineering processes at Legit Global before Legit closed the window of opportunity?

Legit Global had grown rapidly over the last ten years. Newly acquired entities had brought the challenge of integrating additional equipment, personnel, capabilities, and systems. Legit Global had addressed most of these challenges, with more work to be done. They had focused on centralizing the processes of many different functional groups within the company. Functional groups that changed had standardized processes across the company, reduced costs, and increased financial performance. Some employees thought that centralization had increased bureaucracy and slowed operations. To further intensify the dissonance regarding centralization, corporate executives mandated increased oversight from managers, further fueling fears of tighter management control and increased bureaucracy.

The Engineering Department had not kept pace with the other functional groups within the company. Madera had reviewed department practices and discovered most engineering resources and processes existed in silos and were controlled by the Division Vice President (VP). Progress had always been reported by each lead division engineer directly to the VP, then reported to Legit.

Was the research that Madera conducted enough to make a compelling case for centralized operations amidst the inevitable resistance from functional VPs? How would he implement and fund centralized engineering processes at Legit Global? Was there a technology platform that could help centralize Engineering? Were centralized processes the key to Legit Global's future success?

${ }^{1}$ Copyright (C) 2020, Kevin Deary, Tina Herig, Brent Hinson, Eric Martinez. This case was prepared for the purpose of class discussion, and not to illustrate the effective or ineffective handling of an administrative situation. Names and some information have been disguised. This case is published under a Creative Commons BY-NC license. Permission is granted to copy and distribute this case for non-commercial purposes, in both printed and electronic formats. 


\section{Building Products Industry}

The building products industry included manufacturers of building components, home improvement products, and equipment. The industry grew year over year as technology evolved. Manufacturers applied new ways of producing materials to their production line, which aided the companies in becoming more efficient and reducing costs. Considered a cyclical industry, building products companies had shown a rapid decline in earnings before interest, tax, depreciation, and amortization (EBITDA) when the broader market took a downturn. Tight credit metrics left less room for building material producers to maneuver when stressed (Panichi, Nadramia, Michel, Huang \& Seguier, 2018). (See Exhibit 1).

\section{Legit Global Key Competitors}

In the U.S. residential interior window market, the primary participants were Legit Global and WELDJEN, which are the only vertically integrated manufacturers of windows. Legit Global had $14.58 \%$ market share which was $2^{\text {nd }}$ to its competitor WELD-JEN. WELD-JEN was a larger company with more global presence than Legit and carried other products in addition to windows that were offered as a package to customers. In the U.S. residential exterior window market, the primary participants were Legit Global, WELD-JEN, Windowpro, See-Thru, and Feather Lake. In the commercial window market, the leading players were Legit Global and GTT . Design characteristics, brand awareness, product quality, and value were critical factors for competition within the markets.

Legit Global reported a total revenue decrease of $0.67 \%$ in the second quarter of 2019 , while competitors reported a revenue increase of $2.98 \%$. A net margin of $4.46 \%$ also meant that Legit Global was less profitable than its competitors. Revenue loss and slim margins drove Legit Global to prioritize cost reduction. Centralization in the Engineering Department was an important option to cut costs and realize Madera's vision.

\section{Key Assumptions}

In 2019, U.S. expected a 2.3\% growth in the building products industry, $3.6 \%$ unemployment, and an estimated 1.3 million housing starts were forecasted in the U.S. The U.S. further expected mid-singledigit growth in repair and remodeling activity, a $2.8 \%$ growth in nonresidential construction, and infrastructure spending to be flat. These modestly positive fundamentals indicated another year of improved sales and earnings for building materials companies. Growth in 2019 was much less than recorded figures in 2016 and 2017 as the long slow recovery in housing appeared to have plateaued and was forecasted to be flat by 2020 (Panichi et al, 2018). Slowing growth, industry predictions, and market trends caused Legit Global to adjust priorities and focus efforts towards reducing internal costs.

\section{Key Risks and Opportunities}

Historically, when interest rates increased, purchases of new homes or major renovations decreased. This, in turn, resulted in less profit as building materials are impacted as consumers focus on purchasing midrange building materials instead of higher-end premium products.

North American building materials companies had seen their balance sheets and profit margins fully recover from the 2007 Great Recession. However, financial policies remained relatively conservative despite increased cash balances. Issuers preferred to reinvest their excess cash in internal operational improvements or maintain capital on the balance sheet as opposed to paying elevated multiples for acquisitions. If U.S. construction markets slowed and issuers' stock prices dropped, companies would be tempted to use excess cash to repurchase shares or make acquisitions. Repurchased shares added the risk of increased debt, particularly if significant repurchases were made before a turn in the cycle (Panichi et 
al, 2018). These vital economic factors in the building products industry forced companies like Legit Global and its competitors to seek increased profitability through reduced costs.

\section{What is Engineering?}

Engineering is defined as "the application of science and mathematics by which the properties of matter and the sources of energy in nature are made useful to people" (Meriam Webster Dictionary, 2019). The scale and relative complexity of what humans designed and manufactured had increased throughout our history, but the concept of engineering dates to prehistoric times when levers and wheels were first used. The word "engineer" was first used as a military term. Catapults and other complicated machines, called siege engines, were needed to defeat fortifications and the men who operated these engines were called engineers.

In the Medieval era, the concept of mechanical arts included various practical subjects and activities like agriculture, architecture, and blacksmithing. These mechanical arts were considered servile and beneath more noble pursuits like liberal arts. Gradually, these mechanical arts were incorporated into the profession of engineering, which changed the common usage of the word "engineering" towards a term more recognized today: the design and manufacture of complex products (Merriam Webster, 2019).

Engineering could be divided into many different disciplines: civil engineering, mechanical engineering, electrical engineering, chemical engineering, and many others. For this case, civil and mechanical engineering were most relevant. Civil engineering deals with the design, construction, and maintenance of the physical world, while mechanical engineering deals with the design, manufacturing, and maintenance of mechanical systems. These disciplines were essential to designing and building the static elements and moving pieces of Legit Global's many products.

\section{Engineering in the Construction Business}

The engineering and construction industry played an integral role in building the future of the modern world amidst several potential obstacles such as material price volatility, talent shortages, and the rate at which technology changed and evolved (Meisels, 2019).

The future of building materials was going to be shaped by changes in four areas:

1. Panelized/Modular Construction - Owners, developers, builders, contractors, start-ups, and even architects were shifting to panelized/modular products while manufacturers dragged their feet, unconvinced modular construction was significant.

2. Online Information and Sales - Building materials customers were way ahead of manufacturers and suppliers in the way they made online purchase decisions.

3. Labor - Local governments, unions, and entrepreneurs had developed training programs and better ways to connect labor with employers; meanwhile, manufacturers sat on the sidelines.

4. Globalization - International companies performed better at international sales than most US companies. They were now poised to become serious competitors, globally and in North America. (Eiken, n.d.).

Legit Global had aligned its strategic plans globally to stay ahead of its competitors by focusing on four key things: process automation, online ordering, and technology (including RFID chips to track inventory), installation at customers' sites, service after installation. All of these items required 
engineering teams. Madera, as the Director of Strategic Projects, concentrated on these four initiatives and directed engineering support as needed from within the business units.

\section{Legit Global}

Legit Global, headquartered in Lakeland, FL, was a leading global window manufacturer that served residential, commercial, and architectural markets. Legit Global employed over 8000 workers worldwide with several manufacturing sites on four continents.

Legit Global had defined the company mission, purpose, and vision in a document called the Legit Global Roadmap (See Exhibit 2). This document was updated every year and supplied to all of Legit Global employees, customers, and suppliers. This one-page document captured:

- Purpose: Opening Windows for Others

- Vision: To be the best window solutions provider for our customers, employees, shareholders, suppliers, and communities.

- Values: Integrity \& Transparency, Diversity, Teamwork, Flexibility \& Speed, and Innovation.

The company used the roadmap to drive all tactical and strategic decisions, which had helped Legit Global remain relative in a competitive market. The company had grown significantly since 2010 , rising from 6500 to over 8000 employees by 2018. Due to the growth in personnel, the company centralized operations in the Finance, Customer Service, Accounting, and Human Resources Departments. The centralization of these functional groups helped support the vision and values of the company. Legit Global's organization was been sub-divided into four different business units:

1. Residential Window Group - the most significant business unit that manufactured residential windows for wholesale and retail.

2. Commercial Window Group - manufactured windows for commercial and unique markets with more strict and custom requirements.

3. Components Group - Legit Global was considered a vertically integrated company, and this business unit manufactured the components used to produce windows for the Residential, Commercial, and Europe business units.

4. Europe Window Group - manufactured both Residential and Commercial windows for the European market.

Although Legit Global was divided into four business units, a large portion of the manufacturing processes were identical and required similar equipment. The material, finishes, and other unique parameters were the main differences that distinguished the different business units. Legit Global worked in a functional matrix organization. Each business unit, directed by a VP with accompanying staff, made the strategic decisions for the business unit. The business units worked with the Operations team to ensure the product requirements and strategies were communicated to the manufacturing plants to build and fulfill customer orders (See Exhibit 3).

The Legit Global Operations Group was the largest functional group for the company, led by Tad Legit. The Operations Group provided oversight to ensure all manufacturing activities within Legit Global occurred. With over 6000 employees alone, it was the engine of the company. Legit's direct report staff consisted of a VP of Operations for each of the four business units: the Environmental Health and Safety (EHS) VP, the Supply Chain VP, the Schedule Planning Director, and the Continuous Improvement VP. Madera, as the Global Director of Engineering for Strategic and Capital Projects, also resided in the 
Operations Group. The EHS, Supply Chain, Schedule Planning, and Continuous Improvement groups were centralized within Operations and supported all four business units. The Human Resources, Accounting, Finance, and Customer Service Departments were centralized at the headquarters level and supported the Operations Group. These groups had a "dotted-line" reporting responsibility to Legit.

Each VP of Operations was afforded a staff that consisted of one Engineering Manager, one Quality Manager, and a Director of Operations for each subgroup. The Directors of Operations were responsible for all the manufacturing plants and associated personnel. The Engineering and Quality Department did not function as a centralized organization and created a whole host of inefficiencies within the department.

Edgar Madera, was part of the Operations Group Leadership Team. Madera was an engineer with over 20 years of experience and 13 of those years were in Global Legit. He worked in different roles from Six Sigma Master Black Belt, Director of Engineering of two of the different business units (Residential and Commercial). He was also a Project Management Professional (PMP) and had vast experience managing large scale projects. He knew the business very well and was highly demanded for project opportunities or troubleshooting in the entire company. He was in high demand between the VPs and because of this, the CEO decided to promote Madera to Global Director for Strategic Projects to oversee all the strategic projects in 2016. Madera started to report to the Operations Leadership team and work side by side with the Operations VPs. Madera had dotted line responsibility over the engineering groups in all of the business units. But this was the issue that Legit wanted to fix, as each business unit was operating independently and with inefficiencies. Legit assigned Madera with fixing these inefficiencies while remaining focused on the strategic projects for automation and technology. This task was strategic in nature and fit in the project portfolio that Madera was working on. The large-scale projects that Madera is responsible for were of vital importance to Legit Global's ongoing operations. Madera had to research the pros and cons of centralized operations in the Engineering and Quality Departments and recommend a strategy to Legit. He had already received plenty of opposition to centralized operations from the various business units based on fears that centralization would incur cumbersome oversight from upper management and slow decision making. Madera was expected to solve the problem quickly and with compelling results.

\section{Engineering Organizations in Legit Global International}

Experience showed Legit Global's current engineering organizations operated in silos. Each business unit had an independent engineering organization and unique structure. The first engineering organization was developed for the Commercial business unit in 2012 and operated with three engineers: the Engineering Manager, a Division Project Engineer, and a Division Process/Manufacturing Engineer. Supporting over 500 employees, these engineers planned and executed capital projects, worked to improve operational efficiency, and led problem root cause analysis. The business unit started reaping the benefits of this new organization right away, causing the organization to double in size over the first year. Recognizing the benefits, Legit Global applied this structure to the other two divisions in North America. The rapid growth of these organizations within the business unit and across the company led to unique structures and processes tailored to the needs of each business unit. Each engineering organization had a manager or director leading the organization that reported to the operations VP. The priorities were defined between the Operations VP and the business unit leader VP. The Engineering Manager/Director assigned and delegated the work within their engineering organization. 
Centralization of other functional groups within Legit Global had led to standardized forms used by the engineers. Despite this, there were many inconsistencies across the business units related to the planning, execution, and management of capital projects. These projects were critical investments in land, facilities, and machinery, and these inconsistencies created unnecessary delays in approvals, contracts, and payments. Madera quickly determined that standardized processes were required within the Engineering Department, especially for capital projects. He also recognized the lack of communication between the engineering groups and how the inability to prioritize tasks impacted payments.

Another of his observations was the lack of shared practices and resources amongst the Engineering groups. Processes were being implemented successfully, but best practices were not shared between the different business units. Project management differed between business units and revealed the lack of standardization within the engineering department. Project Managers used different templates and processes to complete projects. Some of them weren't even trained on the principles of planning and executing projects.

There were also subject matter experts (SME) for specific processes and equipment. These SMEs did not volunteer their expertise unless specifically requested to do so and had to seek authorization from management to share knowledge with other business units. Resources were budgeted and allocated per business unit so sharing outside of the primary business unit created complications as resources were expended on another business unit without being replenished.

\section{Centralization vs. Decentralization}

Centralization, in this case, was defined as a process in which the planning and decisions were made under a single authority within each respective department at Legit Global. These decision-makers primarily resided in the head office. Lower level decisions were filtered through decision-makers for approval; hence, the term centralized.

Madera researched the advantages and disadvantages of centralized operations within the industry. The advantages of a centralized organization included:

- A clearly defined chain of command - Everyone in the organization knew who reported to who. The organization's structure showed clear roles and responsibilities for each person in the organization.

- Focused vision - Clear goals and objectives of the organization were defined and shared throughout the entire organization.

- Reduced costs - Reduced costs are achieved through standardized processes and methods in the organization.

- Rapidly implemented decisions - a structured chain of command made decisions and sped the rate of implemented decisions.

- Improved quality of work - standardized processes and procedures led to best practices shared with and understood by all in the organization.

The disadvantages of a centralized organization included:

- Bureaucratic leadership - decisions resided with senior executives and employees felt disengaged or not part of the decision making. Disconnected employees impacted the overall productivity of the team. 
- Remote control - The leader of the centralized organization made decisions to be implemented by the employees. Leaders risked losing direct control over the implemented decision.

- Delayed work - Centrally made decisions removed authority from the employees and resulted in deferred action.

- Decreased motivation - In large centralized organizations, employees performed tasks based on the leadership direction, limiting the creativity and commitment of the employees.

Madera researched what each of these advantages and disadvantages meant for Legit Global and intended to provide a comprehensive report to Legit. To gather information, he reviewed current engineering processes and interviewed many functional group leaders, VPs of Operations, engineering leaders, and engineers about centralized operations. His research, although not fully completed, provided enough objective facts to develop several courses of action supporting centralized engineering processes at Legit Global (See Exhibit 4).

\section{Technology in Centralization}

The technology to implement process centralization required a cost analysis establishing the cost associated with implementing a centralized system inclusive of the entirety of the Engineering Department at Legit Global. Madera had options to choose from when considering the best solution at Legit Global. Technical solutions potentially resided in-house in terms of purchased servers and software to support the requirement, or as an outsourced solution in the form of cloud computing. Cloud computing offered services such as Infrastructure as a Service (IaaS), offering highly scalable databases, or Platform as a Service (PaaS), focused more on workflow and process solutions (Knorr, 2018).

"By implementing a single, centralized management solution across the organization, it's possible to see a single version of the truth across all operations - and this dynamically unlocks value by actively managing performance, thereby supporting business process change" (Deal, 2015).

Before a solution was chosen, a proper assessment of company requirements had to be performed. Technology planning, or the process of planning the technical evolution of a program or system, to achieve a desired end-state or vision ("Technology Planning," 2019). (See Exhibit 5). The technology plan assessed and provided guidance on the technological needs of the company and identified a technical solution. This technical solution provided a framework to address the way ahead with senior executives, decision-makers, and stakeholders ("Technology Planning," 2019). The technology plan was flexible and focused on the organization, specific system requirements, and supported an enterprise technical solution. The technology plan was aligned with the strategy and mission objectives of the company; as the technology, plan served as the "roadmap for satisfying the gaps over time to achieve the end-state" (“Technology Planning”, 2019).

\section{Technology Options}

\section{Platform as a Service (PaaS)}

Platform as a service (PaaS) was a service, or a set of services and workflows, in which the users used shared tools or processes to accelerate the testing, development and the deployment of an application (Knorr, 2018). The benefit to PaaS was specific to developers who had access to a wide array of resources and allowed the standardization of processes to follow through the services offered. The underlying 
infrastructure was maintained by the company (Knorr, 2018). PaaS services were similar to Software as a Service (SaaS), except PaaS services were delivered as a platform over the internet for a subscriber to create software, and not strictly use software (Watts \& Raza, 2019). Companies like Salesforce.com offered access and use of their PaaS for subscribed companies. Services from a PaaS platform saved costs associated with developing applications for company use. PaaS providers reduced the need to hire developers within the company and performed the development of required applications based on company requirements ("The Advantages of PaaS: Leveraging a Platform to Add Value," 2019). PaaS services were not necessarily an end-state solution to centralized processes at Legit Global International; instead, they were a complement to a chosen solution. An additional consideration of PaaS was information security. Although the infrastructure was maintained by the company, data that is released to the PaaS provider was received and stored by the provider. The output product was modified and developed within the code standards of the PaaS provider ("The Advantages of PaaS: Leveraging a Platform to Add Value," 2019). (See Exhibit 6).

\section{Infrastructure as a Service (laaS)}

Infrastructure as a Service (IaaS), better applied to a centralized enterprise solution, offered data storage and computed services on a pay-per-use basis (Knorr, 2018). Services such as access to databases, big data analytics, and developer tools were offered as part of IaaS services. Providers such as Amazon, Google, and IBM offered IaaS services (Knorr, 2018). IaaS reduced the costs associated with purchased servers and related hardware (R\&G Technologies, 2014). IaaS was a more integrated service that developed and managed company requirements and provided a centralized solution to use without the need to acquire additional equipment. Alignment with the wrong IaaS provider was costly if security protocols followed were not enough to protect company data. IaaS had limitless scalability options, as the provider accommodated the data and processing requirements of the supported company ( $R \& G$ Technologies, 2014). IaaS was a stand-alone option for a company seeking services, as the services provided were tailored to the needs of the company. Data storage, as the requirement grew, increased the cost as the provider utilized more computing power and storage space to accommodate. Like PaaS services, data released to an IaaS provider was susceptible to a security breach and potentially lost if the provider experienced a mishap with data storage servers.

"Conceptually, the most "centralized" type of business continuity program is one in which a third-party that specializes in business continuity is tasked with conducting all program activities in an outsourced capacity" (Perry, 2017).

\section{Center of Excellence}

Cloud computing was a viable option to centralize processes at Legit Global but not the only option. The technology planning process identified cloud computing services may not meet the data storage and security requirements of Legit Global. A center of excellence $(\mathrm{CoE})$ was a shared services model that utilized shared services to "employ key levers such as scale, end-to-end process governance, standardization, and, of course, centralization" focused on the pursuit of excellence in the designated area of study (Cavalier, 2019). CoE's functioned off a clearly defined vision and strategy of the company and established structured governance, efficient processes, and employed automated solutions (Cavalier, 2019).

A CoE based on a critical process assists the entire organization to standardize and become efficient in executing the adopted process. A CoE typically consists of a cross-functional representation from various functional areas within the company to establish a forum in which to collaborate and standardize necessary processes. CoE's are designed to be an interactive process and intended to mature over time. As 
a company evolves over time, a CoE must adjust to the changes within the company (Schechter, 2017). A CoE manages the framework related to the developed process, while the various Departments perform functions within the developed framework.

A mature CoE continuously delivered added value to a company. As developed processes became standardized practices within the company, efficiencies were achieved. A CoE provided an opportunity to centralize processes to be followed and were distributed to the workforce. Developed processes eliminated common functions being performed in a silo. Compliance standards were applied to input data and ensured that data being used was valid, duplicate free, and within established standards. Established compliance standards reduced risk to the company and increased efficiency in operations. Additionally, a duplicated CoE model was available to be shared with other departments within the company.

A CoE incurred additional costs to the company to ensure centralized processes and compliance standards were adequately developed and implemented. Aside from the computer and server requirements necessary to establish a CoE, consideration for a person, or team of people, were essential for an organized and functioning $\mathrm{CoE}$. The established $\mathrm{CoE}$ required a multi-disciplinary staff decision, as things like new equipment, additional personnel, and potentially changing company practices were up for decision. A CoE could not survive primarily through the desired will of the primary manager. An effective CoE manager needed to continuously envision the needs and requirements of the company work to address those challenges.

"Building a CoE, and making excellence a habit, is a journey - one that will entail careful thought, planning, and execution to build differentiating capabilities that deliver tangible value to the business and its stakeholders" (Cavalier, 2019).

\section{Strategic Management Strategy}

Another available option, especially if funds for equipment upgrades and outsourced services were not available, was the strategic management strategy. Kaplan and Norton believed "a balanced scorecard framework is the best way to align strategy and structure within an organization" (2006). This scorecard framework (see Exhibit 7) was used to drive the performance of the company, defined and communicated the cause-and-effect relationships, and provided the ability to ensure the company strategy was being implemented (Kaplan \& Norton, 2006). The scorecard measures the perspective of the customer, internal company perspective, innovation and learning perspective, and the financial perspective. Companies insert goals related to time, quality, performance and service, and translate these goals into specific measured. This scorecard strategy aligned corporate and business unit strategy and encouraged business units to develop similar strategies that contributed to established company-level objectives (Kaplan \& Norton, 2006). Essentially, this strategy forced managers to not only focus on individual business units but simultaneously keep an eye on the goals of the company as well, which reduced silo planning. Established program management tools, such as Six Sigma, were employed to improve the productivity and standardization of business units (Kaplan \& Norton, 2006). Collaboration between managers and executive leadership were essential in this process, and ensured strategies were aligned. Periodic checks measured the effectiveness of the business units.

"Given the costs and difficulties involved in finding structural ways to unlock value, it is fair to raise the question: Is structural change the right tool for the job? We believe the answer is usually no." (Kaplan \& Norton, 2006). 


\section{The Decision}

Upon completion of his observations, Madera compiled all his findings and met with many functional groups, including Legit, to understand the needs of each group. Madera was faced with several decisions, each one possessing unique advantages and disadvantages. Madera needed to take into consideration that the course of action chosen needed to have a positive impact on the future engineering strategies for Legit Global specifically the automation of processes, online ordering, and technology implementation (RFID). Madera needed to present a recommended course of action to the Legit Global Leadership Team to either centralize engineering or not. Madera had the following options:

Table 1: Madera's Options

\begin{tabular}{|c|c|c|c|}
\hline Option & Benefits & Cons/Risks & Implementation Costs \\
\hline Do Nothing & $\begin{array}{l}\text { A delayed decision to } \\
\text { centralize engineering } \\
\text { processes allowed } \\
\text { engineering groups to } \\
\text { maintain alignment with } \\
\text { individual business unit } \\
\text { operating plans. The do- } \\
\text { nothing option is a low- } \\
\text { cost option to maintain } \\
\text { "business as usual." }\end{array}$ & $\begin{array}{l}\text { Centralization disrupted } \\
\text { processes and created } \\
\text { anxiety among workers. } \\
\text { Stress caused the delay of } \\
\text { work, and employee } \\
\text { turnover resulted. }\end{array}$ & None \\
\hline $\begin{array}{l}\text { Hybrid Engineering } \\
\text { Organization }\end{array}$ & $\begin{array}{l}\text { Established a small staff } \\
\text { to provide oversight of } \\
\text { centralized engineering } \\
\text { processes. Ensured } \\
\text { processes were } \\
\text { standardized, best } \\
\text { practices were shared } \\
\text { amongst departments, and } \\
\text { a CoE was established } \\
\text { and properly managed. } \\
\text { This solution required } \\
\text { engineering resources be } \\
\text { reported to the Operations } \\
\text { Group VP and dotted } \\
\text { (indirect) reporting to the } \\
\text { centralized Engineering } \\
\text { leader. }\end{array}$ & $\begin{array}{l}\text { New reporting standards } \\
\text { potentially would create } \\
\text { confusion over existing } \\
\text { priorities between the } \\
\text { engineering leaders in } \\
\text { each business unit as } \\
\text { direct managers typically } \\
\text { assigned work to each } \\
\text { business unit. }\end{array}$ & $\begin{array}{l}\text { Medium - This solution } \\
\text { required new employees to } \\
\text { be hired and the time } \\
\text { required to train and } \\
\text { develop new employees. }\end{array}$ \\
\hline
\end{tabular}




\begin{tabular}{|c|c|c|c|}
\hline $\begin{array}{l}\text { Full Centralization of } \\
\text { Engineering Globally }\end{array}$ & $\begin{array}{l}\text { All engineering resources } \\
\text { were centralized under } \\
\text { one leader with all the } \\
\text { benefits of the Hybrid } \\
\text { Organization solution. } \\
\text { Centralized processes } \\
\text { required hiring additional } \\
\text { personnel to outfit the } \\
\text { CoEs. In this option, most } \\
\text { of the Engineering } \\
\text { resources already existed. } \\
\text { Engineering resources } \\
\text { now worked across } \\
\text { multiple business units } \\
\text { and were prioritized based } \\
\text { on the needs of the } \\
\text { company. }\end{array}$ & $\begin{array}{l}\text { Projects were no longer } \\
\text { dictated and controlled by } \\
\text { direct line supervisors. } \\
\text { Some engineers viewed } \\
\text { full centralization as a } \\
\text { growth opportunity, but } \\
\text { the VPs of the Operations } \\
\text { Group and individual } \\
\text { business units envisioned } \\
\text { centralization created a } \\
\text { loss of control over } \\
\text { business unit engineering } \\
\text { resources and would fall } \\
\text { behind in planned } \\
\text { operating objectives if the } \\
\text { engineering staff was } \\
\text { deployed to another } \\
\text { business unit. }\end{array}$ & $\begin{array}{l}\text { Low - This solution will } \\
\text { require some } \\
\text { administration employees } \\
\text { to support the entire } \\
\text { organization }\end{array}$ \\
\hline $\begin{array}{l}\text { Outsource the } \\
\text { Development of } \\
\text { Standards and Procedures } \\
\text { for All Engineering } \\
\text { Groups }\end{array}$ & $\begin{array}{l}\text { Outsourced engineering } \\
\text { services across the } \\
\text { multiple engineering } \\
\text { groups. This option } \\
\text { utilized technology } \\
\text { platforms, such as PaaS or } \\
\text { IaaS, as a repository to } \\
\text { keep the forms, } \\
\text { procedures, and shared } \\
\text { best practices accessible } \\
\text { to all engineers in Legit } \\
\text { Global. After the solution } \\
\text { was implemented, an } \\
\text { appointed leader from } \\
\text { Legit Global would be } \\
\text { chosen to ensure } \\
\text { processes were adequately } \\
\text { managed, monitored, and } \\
\text { enforced among all the } \\
\text { engineering groups to } \\
\text { ensure compliance. }\end{array}$ & $\begin{array}{l}\text { The outsourced } \\
\text { engineering option will } \\
\text { take time to be effective } \\
\text { as there will be a learning } \\
\text { curve for many of the new } \\
\text { employees. This could } \\
\text { take years to implement. }\end{array}$ & $\begin{array}{l}\text { High - This solution would } \\
\text { be costly to implement, as } \\
\text { most of the development of } \\
\text { the solution is outsourced }\end{array}$ \\
\hline
\end{tabular}




\section{References}

Cavalier, J. (2019). Using centers of excellence to change the game. Retrieved from https://www.cohencpa.com/insights/articles/using-centers-of-excellence-to-change-the-game

Deal, K. (2015). 5 simple steps to a centralized ERP solution. Retrieved from https://www.manufacturing.net/article/2015/09/5-simple-steps-centralized-erp-solution

Eiken, T. (n.d.). The future of building materials. Retrieved from https://www.seethewhizard.com/blog/future-of-building-materials/

Kaplan, R., \& Norton, D. (2006, March). How to implement a new strategy without disrupting your organization. Harvard Business Review. Retrieved from https://hbr.org/2006/03/how-toimplement-a-new-strategy-without-disrupting-your-organization

Knorr, E. (2018). What is cloud computing? Everything you need to know now. Retrieved from https://www.infoworld.com/article/2683784/what-is-cloud-computing.html

Meisels, M. (2019). 2019 engineering and construction industry outlook. Retrieved from https://www2.deloitte.com/us/en/pages/energy-and-resources/articles/engineering-andconstruction-industry-trends.html

Panichi, R., Nadramia, T., Michel, A., Huang, D., \& Seguier, P. (2018). Industry top trends 2019 building materials. Retrieved from https://www.spratings.com/documents/20184/5670590/Industry+Top+Trends+2019++Building+Materials/912d0b2c-1117-e17b-2b2b-94d300d67d24

Perry, M. (2017). Business continuity planning: centralized and decentralized approaches. Retrieved from https://avalution.com/business-continuity-planning-centralized-and-decentralizedapproaches

R\&G Technologies. (2014). 3 reasons why you should consider infrastructure as a service (IaaS). Retrieved from http://blog.rgtechnologies.com.au/infrastructure-as-a-service-benefits

Schechter, J. (2017). Center of excellence (why create one?). Retrieved from https://www.onespan.com/blog/center-excellence-why-create-one

Technology Planning. (2019). Retrieved from https://www.mitre.org/publications/systems-engineeringguide/acquisition-systems-engineering/acquisition-program-planning/technology-planning

The Advantages of PaaS: Leveraging a Platform to Add Value. (2019). Retrieved from https://liquidstate.com/advantages-paas-platform-as-a-service/

Merriam-Webster Dictionary (2019). Retrieved from https://www.merriam-webster.com/

Watts, S., \& Raza, M. (2019). SaaS vs. PaaS vs. IaaS: what's the difference and how to choose. Retrieved from https://www.bmc.com/blogs/saas-vs-paas-vs-iaas-whats-the-difference-and-how-to-choose/ 


\section{Biographies}



Kevin Deary is a graduate of the USF Executive MBA program. Deary is currently a government civilian at the United States Special Operations Command at MacDill Air Force Base in Tampa. There, he reviews plans and actions to make sure they are compliant with existing policies. Deary retired from the U.S. Army after more than 25 years' service in special operations. Deary is experienced in management, liaison development, team building, operations execution, training, and evaluation. Deary received a bachelor's degree in Strategic Studies and Defense Analysis from Norwich University in Vermont

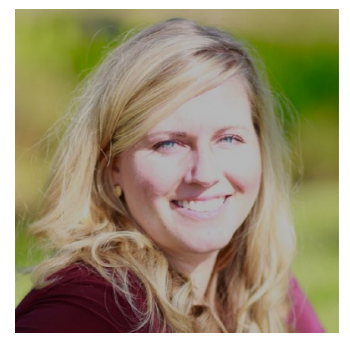

Tina Herig is a graduate of the USF Executive MBA program. Herig is currently the director at Client Success Response Center, a professional employer organization that provides small and midsize businesses with a full-service HR solution. Her job includes oversight of coaching and mentoring of employees and garnering the trust of her business and corporate clients. She oversees an organization which focuses on partnering and providing world-class customer service to the company's clients. Herig received a bachelor's degree in management from USF Sarasota-Manatee.

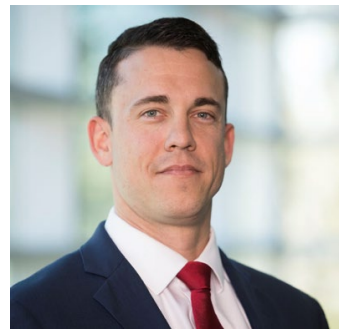

Brent Hinson is a graduate of the USF Executive MBA program. Currently, Hinson is a Neuromodulation Sales Representative with Medtronic. He sells a wide variety of products, including spinal cord stimulators and intrathecal drug pumps, to physicians, administrators, and executives. He is responsible for over $\$ 2$ million in revenue per year, as well as providing direct intra-operative support and guidance during surgeries. Prior to joining Medtronic, he served in the United States Army as an Infantryman. Hinson received a bachelor's degree in Biomedical Sciences from USF.

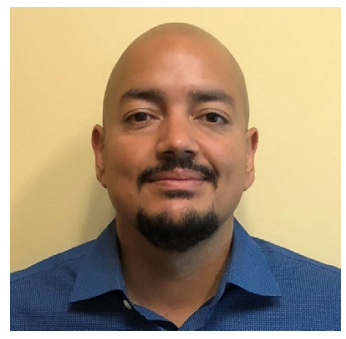

Eric Martinez is a graduate of the USF Executive MBA program and currently works for a global door manufacturing company with headquarters in Tampa and more than 9,000 employees. He is the Global Engineering Director for Strategic Projects and is responsible for leading the company's most significant strategic projects, including capital, productivity, and new business acquisitions projects. He has 18 years of work experience and has been in leadership roles for 13 of those years. Martinez received a master's degree in engineering management from USF and a bachelor's degree in mechanical engineering from the University of

Puerto Rico. 


\section{Exhibit 1: Legit Global second Quarter 2019 Results}

Executive Summary - 2Q19 versus 2Q18:

- Net sales decreased 1\% to $\$ 563$ million versus $\$ 567$ million. Excluding the impact of foreign exchange, net sales increased $1 \%$.

- Net income attributable to Legit Global was \$24 million compared to \$35 million, and diluted earnings per share decreased to $\$ 0.96$ from $\$ 1.24$.

- Adjusted earnings per share* decreased to $\$ 1.09$ from $\$ 1.24$. Adjusted earnings per share* excludes charges of $\$ 3$ million related to our previously announced restructuring and divestiture of non-core businesses.

- Adjusted EBITDA* increased 2\% to $\$ 80$ million versus $\$ 78$ million.

- Repurchased 307,786 shares of Legit Global stock in the second quarter for approximately $\$ 15$ million.

- Updated annual outlook for net sales growth to 0 - 2\%; adjusted EBITDA* to \$275 - \$295 million

Source: Legit Global 2019 Second Quarter Results. Adapted and disguised by authors from original company website. 
Exhibit 2: Legit Global Roadmap

\section{Legit clobal Roadmap}

PURPOSE Opening Windows for Others

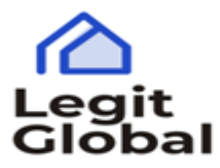

VISION Be the Best Window Solutions Provider for:

- Customers

- Employees and Shareholders

- Suppliers

- The Community

VALUES Legit Global Values

- Integrity and Transparency

- Diversity

- Teamwork

- Flexibility and Speed

- Innovation

Source: Legit Global Roadmap (2019). Developed and modified by authors. 


\section{Exhibit 3: Legit Global Operations Organization Chart}

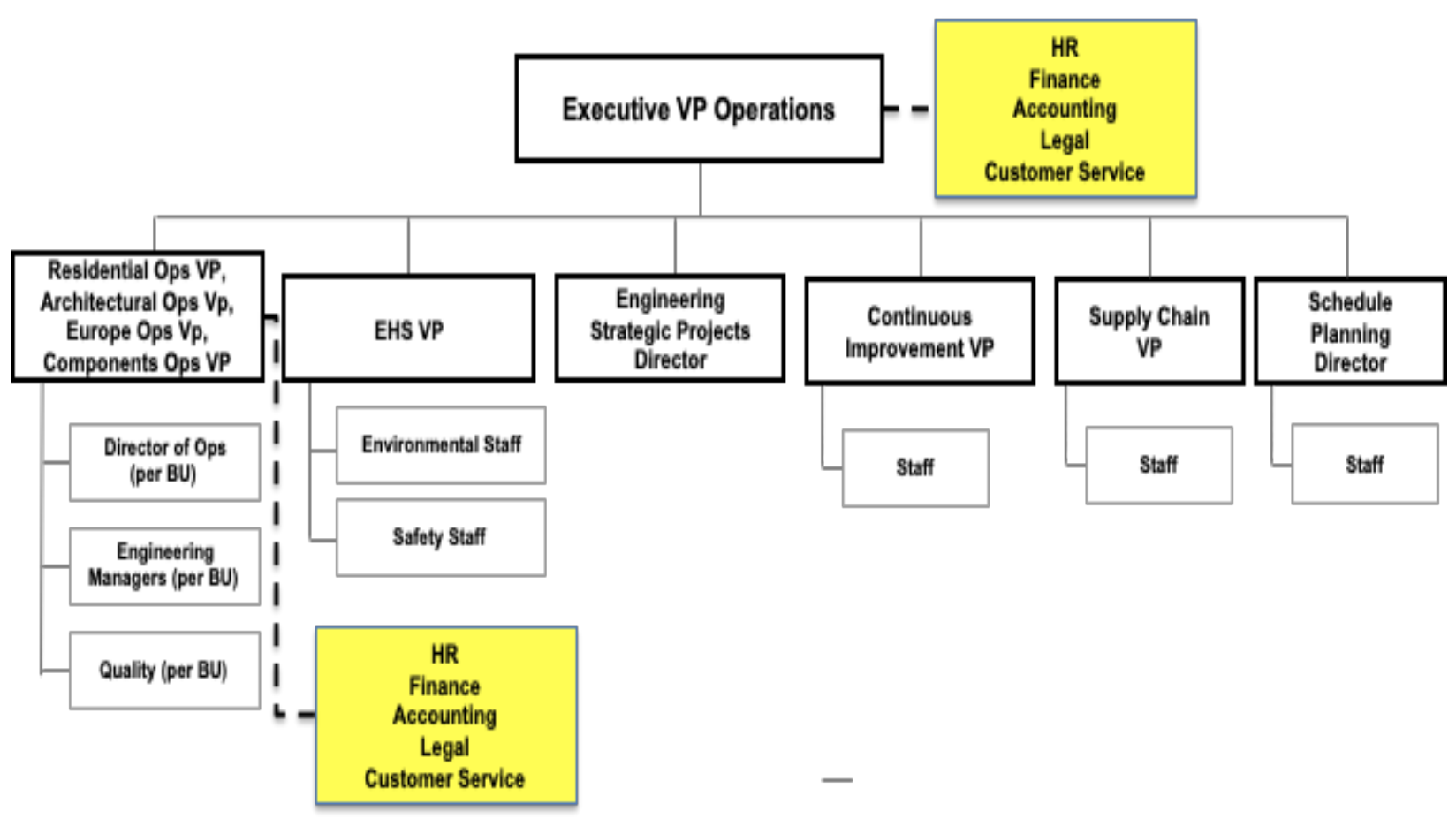

Source: Legit Global Operations Organization Chart (2019). Developed and modified by authors. 


\section{Exhibit 4: Madera's Research Findings Summary}

\begin{tabular}{|c|c|}
\hline Advantages & Impact to Legit Global \\
\hline $\begin{array}{l}\text { Clear Chains of } \\
\text { Command }\end{array}$ & $\begin{array}{l}\text { Improved efficiency at Legit Global. The current process created confusion over the } \\
\text { approved project and related decision timelines. For example, large capital projects } \\
\text { required authority from the VPs of different business units. VP approval required time } \\
\text { and incorporated unnecessary staff reciprocation. Centralized operations implemented by } \\
\text { each independent business unit would ensure all requests are completed and vetted } \\
\text { through the Engineering and Finance Departments before requests are presented to Legit } \\
\text { Global senior leaders. }\end{array}$ \\
\hline Focused Vision & $\begin{array}{l}\text { Goals and objectives clearly defined for all business units in Legit Global. The impact of } \\
\text { an engineering decision in one business unit potentially impacted other engineering } \\
\text { business units. The building materials industry was a volatile market and forced Legit } \\
\text { Global senior executives to change company priorities throughout the year. A clear } \\
\text { vision was necessary to keep the engineering organization aligned with the interests of } \\
\text { the entire company. Centralized operations managed the capital budget at a higher level } \\
\text { and allocated funds appropriately to keep project deadlines in scope. }\end{array}$ \\
\hline Reduced Costs & $\begin{array}{l}\text { Sharing of best practices within engineering organizations would benefit the entire } \\
\text { Department for the better. Madera believed this to be the most crucial benefit of } \\
\text { centralization. A majority of the engineering processes were similar and presented } \\
\text { opportunities to reduce costs through coordination of purchases and } \\
\text { servicing. Centralization would also allow for the consolidation of subject matter expert } \\
\text { (SME) resources within the department. Centralized SME resources would assisted in the } \\
\text { creation of a Center of Excellence }(\mathrm{CoE}) \text { and support significant manufacturing processes } \\
\text { in the company. }\end{array}$ \\
\hline $\begin{array}{l}\text { Quick } \\
\text { Implementation of } \\
\text { Decisions }\end{array}$ & $\begin{array}{l}\text { Expedited decision making was vital to implementing Legit Global's key initiatives. The } \\
\text { sharing of best practices was minimal among the groups and created an issue for } \\
\text { decision-makers during the review and approval process. Different forms were used to } \\
\text { accomplish the same goal in different organizations. A centralized organization would, } \\
\text { with proper training and compliance, select and implement a best practice solution. }\end{array}$ \\
\hline $\begin{array}{l}\text { Improved Quality } \\
\text { Work }\end{array}$ & $\begin{array}{l}\text { Not all engineering processes were standardized in Legit Global. Business units were } \\
\text { operating in silos and utilized internal engineering processes, while business leaders } \\
\text { reviewed projects differently due to a lack of standardized procedures. A single process } \\
\text { for planning, executing, and monitoring projects would improve efficiency. }\end{array}$ \\
\hline
\end{tabular}




\begin{tabular}{|l|l|}
\hline Disadvantages & Impact to Legit Global \\
\hline $\begin{array}{l}\text { Bureaucratic } \\
\text { Leadership }\end{array}$ & $\begin{array}{l}\text { Centralized organizations lead to centralized power structures. Should decision-making } \\
\text { authority reside only with senior executives, employees might feel disengaged and not } \\
\text { participate in finding solutions. Disconnected employees would lead to higher turnover } \\
\text { and lower productivity. }\end{array}$ \\
\hline Remote Control & $\begin{array}{l}\text { Remote control posed an issue if no direct communication existed between the } \\
\text { centralized engineering organization leader and the leaders of the other functional groups } \\
\text { or business units. For example, a decision to reduce travel to save costs could potentially } \\
\text { impact other business units without adequately understanding travel justification. }\end{array}$ \\
\hline Delayed Work & $\begin{array}{l}\text { "Flexibility in Every Fiber" is a pillar of Legit Global culture. Quick decisions were } \\
\text { needed in the volatile building materials industry. Reactive decisions sharpened Legit } \\
\text { Global's competitive edge in the building materials market. Added levels of bureaucracy } \\
\text { could dull this edge. For this reason, some leaders were opposed to a fully centralized } \\
\text { organization due to fear of losing control over the employees and resources they } \\
\text { currently controlled. }\end{array}$ \\
\hline $\begin{array}{l}\text { Decreased } \\
\text { Motivation }\end{array}$ & $\begin{array}{l}\text { Centralization could drain business units of their entrepreneurial spirit and decrease } \\
\text { employee initiative. Employees who only do as they're told are unlikely to innovate and } \\
\text { outproduce the competition. }\end{array}$ \\
\hline
\end{tabular}

Source: Developed and modified by authors. 




Source: Technology Planning. (2019). Retrieved from https://www.mitre.org/publications/systemsengineering-guide/acquisition-systems-engineering/acquisition-program-planning/technology-planning 


\section{Exhibit 6: Technology Options - Cloud Services (SaaS vs. PaaS vs.} laaS) Example

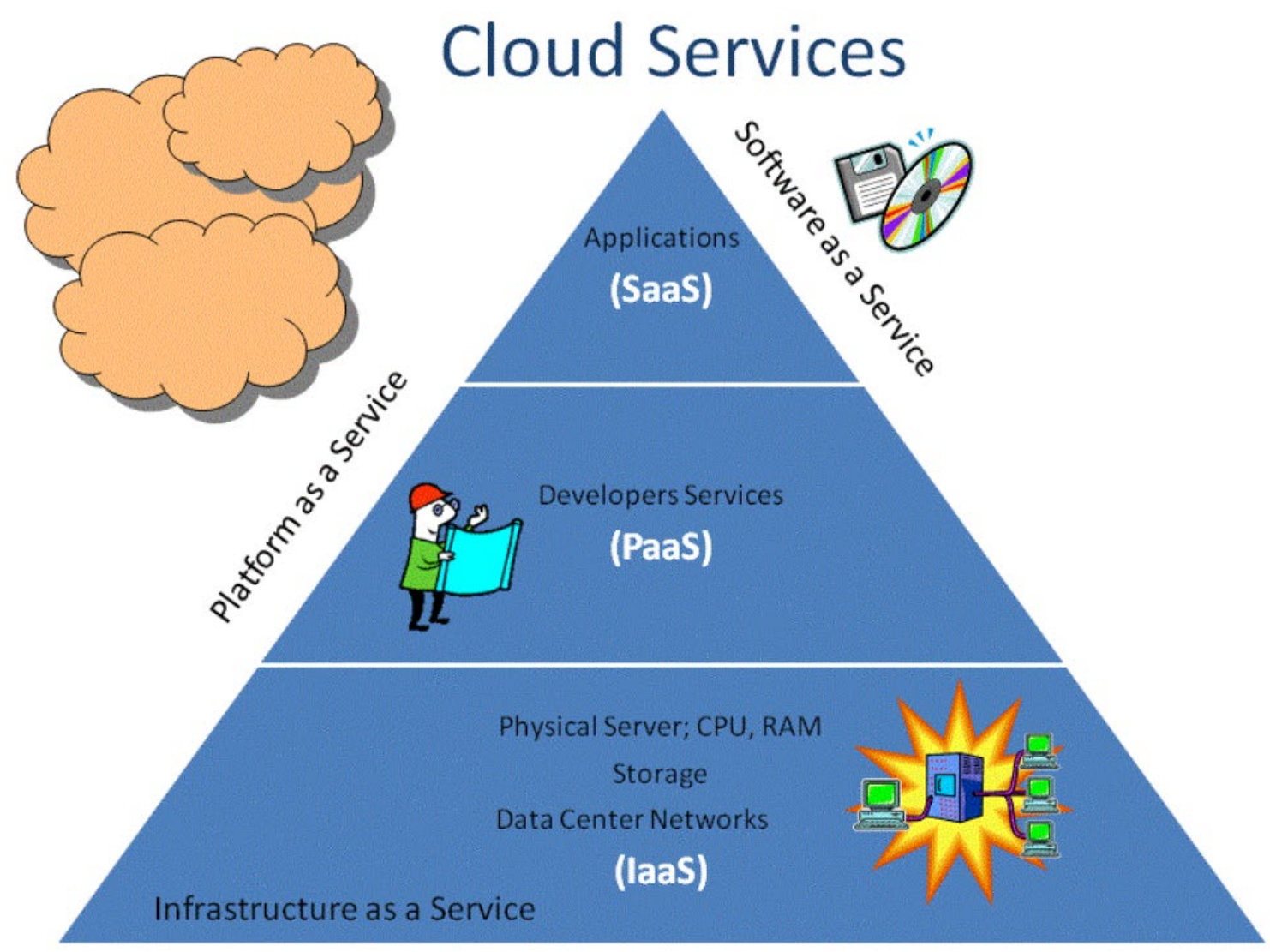

Source: Watts, S., \& Raza, M. (2019). SaaS vs. PaaS vs. IaaS: What's the Difference and How To Choose. Retrieved from https://www.bmc.com/blogs/saas-vs-paas-vs-iaas-whats-the-difference-and-howto-choose/ 


\section{Exhibit 7: The Balanced Scorecard Links Performance Measures}

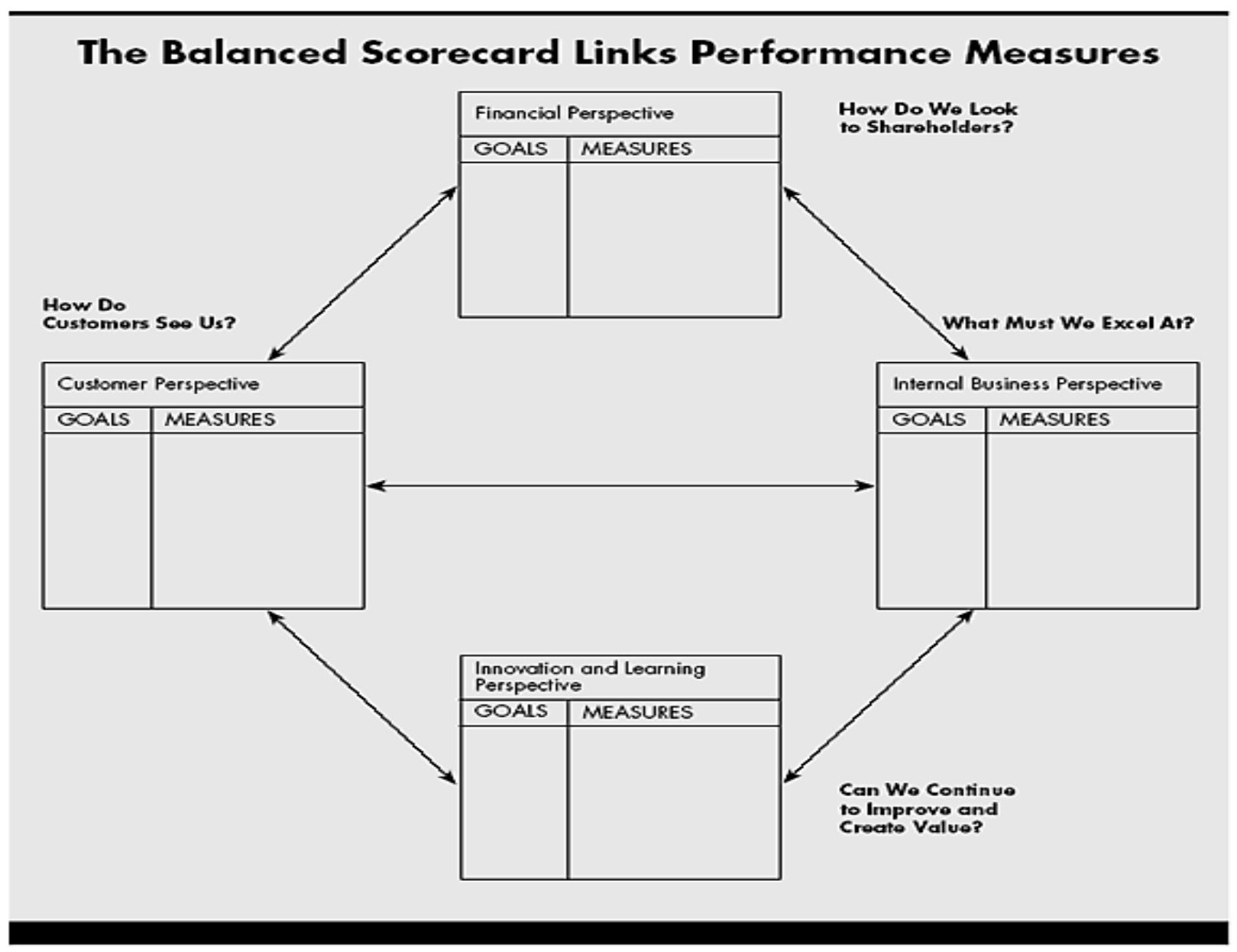

Source: Kaplan \& Norton (2006). 